\title{
Socio-Cultural Factors that Hinders the Domestication of Non-Timber Forest Products (NTFPs) By Farmers in Manyu Division, South West Region of Cameroon
}

\section{Achu Frida Njiei* and Norah Aziamin Asongu}

\author{
National Centre For Education \\ Ministry of Scientific Research and Innovation \\ P. 0 Box 1721 Yaounde Cameroon
}

E-mail: achufri2002@yahoo.com; norahasongu@yahoo.com

*Corresponding author details: Achu Frida Njiei; achufri2002@yahoo.com

\begin{abstract}
This study seeks to examine the socio-cultural challenges faced by the people of Manyu in the domestication of some Non-Timber Forest Products (NTFPs) and the role of the extension workers in enhancing the domestication. Manyu Division has several NTFPs species which are of great benefits to its people. These benefits are not void of socioeconomic, environmental and cultural challenges. These trees species have been domesticated by some members of the community to ease access, enable shorter gestation period, and enhance their economic values. However, despite the importance attached to these domesticated species, some members of the community are reticent in adopting the new domestication strategies. The study made use of the qualitative approach in collecting data for this study with interviews, direct observation, and focus group discussions as our main data collection methods. Results of the study indicate that cultural stereotypes have hindered the domestication of some NTFPs in Manyu Division. However, the extension workers and nongovernmental organizations (NGOs) working in this sector have not relented their efforts in encouraging farmers to domesticate NTFPs in Manyu Division.
\end{abstract}

Keywords: socio-cultural; NTFPs; domestication; extension workers; manyu division; cultural stereotypes; NGOs

\section{INTRODUCTION}

Forest trees have over the ages played a vital role in the ecosystem by providing a wide range of products used as food substitutes and also a wide variety of uses for both urban and rural dwellers in sub-Saharan Africa and elsewhere. More than $45 \%$ of the Cameroonian population live in the rural areas (World Bank, 2012), and it is commonly recognized that NTFPs play key role in the daily life of millions of these rural people (Schreckenbery, 2006). NTFPs serve as a source of livelihood as the rural population depends heavily on the forest and on what nature can offer with little or no knowledge on the domestication of these plants. The rural population exploits the non-timber forest products either for food, to generate income for their families, and the leaves and back of some trees are used as medicines.

The benefits derived from forest trees could be realised by identifying and integrating more trees into the agricultural landscapes the world over. This is obvious because agriculture developed man's ability to identify and domesticate plants that are useful for food, medicine, energy and other uses. In an era of increasing population and growing food insecurity and the quest for achieving food self-sufficiency there is need to domesticate NTFPs species due to their contribution to food self-sufficiency in rural areas. The growing demand for NTFPs species as a result of their nutritional value and their contribution to income generation coupled with poverty alleviation calls for their domestication. NTFPs are retained on farms for obvious reasons that range from ecological, economic and even because of their socio-cultural significance to the people (Ajake and Anim, 2012).

However, many studies have addressed the biology of a number of high-value NTFP species in Central Africa (Moupela et al., 2011), with little known concerning the impact of decreasing forest cover on NTFP availability, accessibility or incomes of forest-dependent people (Gillet et al., 2016). Logging companies fell trees and destroy the biodiversity and ecosystems, creating difficulties to forest communities or rural dwellers who depend upon the trees or plants for means of livelihood (Puliot et al., 2012). Deforestation and forest degradation reduce the availability of NTFPs (De Beer 2011) and have been revealed to have the largest negative impact on the poorest households, as the relative importance of NTFPs for income generation increases with decreasing income from other activities such as agriculture (De Beer 2011).

In west and central Africa, a number of NTFPs and nuts, mostly gathered from farm trees contribute to regional trade (Ndoye et al., 1997). Perhaps because of this trade evidence is accumulating that NTFPs do contribute significantly to household incomes (Gockowski et al., 1997; 
Awono et al., 2002) and to household welfare (Schrenkenberg et al., 2002). Tree crops have also been recognized as a means of achieving resilience against problems of poverty, food and medicine, climate change, and ecosystem degradation (Ingwe et al., 2010). This could alter global nutrition insecurity knowledge because productivity and benefits accruing from products of NTFPs, have not been quantified to depict value added, and the emergence of alternatives which appear to be more lucrative to tree products in terms of food demand. Emerging alternatives to forestry products could be obtained through preservation, processing and storage which are still at rudimentary levels in Cameroon (Ayuk et al, 1999).

Tree domestication emerged as a farmer-driven, market-led process in the early 1990s which evolved through international initiative. A participatory approach now supplements the more traditional aspects of tree improvement. This is seen as an important strategy towards the Sustainable Development Goals by eradicating poverty and hunger, promoting social equity and environmental sustainability (Leakey et al., 2005). Considerable progress has been made towards the domestication of NTFPs and nut trees in many villages located in the agro ecological zones of Cameroon and Nigeria (Leakey, 2005). A combination of indigenous and exotic tree foods in farming systems can provide a year-round supply of important nutrients; raise farmers' incomes through the sale of produce; boost the production of traditional species; and conserve precious indigenous agro biodiversity threatened by deforestation (ICRAF, 2017).

Despite the important role of NTFPs in reducing poverty and hunger, some studies have proven that trading in NTFPs cannot eradicate poverty. According to Sunderlin et al. (2006), the potentials of NTFPs to provide substantial income appears to be limited. There are some isolated cases of success, but by and large the outlook for NTFPbased poverty reduction is not bright. A study of 61 cases of NTFP commercialization in Latin America, Africa, and Asia shows that there are few cases where selling products from unmanaged natural forests have helped lift people out of poverty (Ruíz-Pérez et al., 2004b). The same study concluded that it is often wrong to assume that because a NTFP is important to the poor, efforts to develop it will help the poor (Belcher et al., 2005). Arnold et al. (1997) recommend that a large number of poor people involved in the wood fuel economy should be assisted in finding alternative income sources. This is because the prospects of exiting from poverty through dependence on this source of income are bleak. Although NTFPs are emphasized in this discussion, strong policy attention to the role of NTFPs in livelihoods is fully justified because of their vital role in supporting basic needs, providing seasonal gap filler income, and serving as an emergency safety net (Roger et al., 2010). It is especially considered as an advantage to the existing agricultural system and therefore seen to provide more income generation for individual farmers as well as small holder groups. Moreover, the market chain employments are quite remarkable (Sunderlin et al., 2007). There are several NTFPs with high economic value like "eru" (Gnetum spp leaves), "bush mango" (Irvingia spp almonds), "country onion" (Afrostyrax lepidophyllus) (Ewane et al., 2009; Ingram et al., 2012) which when invested upon could improve income and act as source of medicine for the poor. That is why investment in these species has become a necessity. Unfortunately, in Manyu and other part of Cameroon, these forest trees face threats of extinction since the rural population has little or no knowledge on the domestication of these products. Despite the efforts put in place by the field extension agents to invest in tree planting through domestication, their goal has not been achieved. This is due to socio-cultural beliefs and cultural stereotypes surrounding domestication of NTFPs in Manyu division.

\section{OBJECTIVES OF THE STUDY}

- To examine the socio-cultural factors that hinders the domestication of some NTFPs in Manyu division.

- To verify the role of the extension workers in enhancing tree domestication in Manyu division.

\section{MATERIALS AND METHODS}

Manyu division is located in the South West region of Cameroon and falls under the equatorial rainforest agro ecological zone. Manyu division comprises of four subdivisions: Akwaya, Eyumojock, Mamfe and Upper Bayang. It shares common borders with Nigeria in the West, Widikum subdivision to the North-East, Nweh and Mundani in Libialem division to the East, and Mbo to the South-West. Manyu division is located in a tropical rainforest area with a forest cover of over $90 \%$. Land use change is visible and principally represented by settlements and agricultural land. Forestry companies also carry out selective logging of tropical wood without any information on trees of economic importance to the indigenous population (Ayuk, 2002). As such, forest cover change is highly perceptible around major settlements like Mamfe, Bachu ntai, Osing, Bessonabang and others, where the Bayang and Ejagham population are settled. Areas around settlements have been highly deforested to create cultivable land. Besides food crop production, farming in the area is largely dominated by NTFPs, with cocoa (Theobroma cacao) being a major cash crop. The most important is the inherent agroforestry knowledge and practices implemented by the people during farm creation as farmers do not cut down NTFP species when expanding farmlands into the deep evergreen forests.

\section{THEORETICAL ORIENTATION}

\section{Theory of Diffusion of Innovation}

The theory of diffusion of innovation explains the behaviour of people in rural communities involve in NTFPs how they are adapting to the transitional change, and problems encountered in the integration of NTFPs into agriculture. Although this theory is grounded on innovation sciences, it has been applied recurrently over the past thirty years in different social science disciplines (Shahin, 2006). This theory was developed by Rogers (1962) explaining why/how an idea and/or product spread within a given culture or social system over a given period. According to Rogers (1983), technology or innovations spread through a continuous process referred to as 'diffusion' and this depends on:

- The innovation itself, referred earlier to as 'the process of making changes to something established by introducing something new that adds value to customers (O'Sullivan, 2008: 4);

- Communication channels (means through which people get to know about an innovation);

- Time (rate of adoption and decision-making process)

- The social system in which this is occurring. This theory also highlights the fact that an innovation has to be highly adopted for it to survive. This implies that people, as part of a social system, adopt a new idea, behaviour, or product. Adoption means that a person does something differently than what they had previously done (i.e purchase or use a new product, acquire and perform a new behaviour, etc.). The theory of diffusion of innovation in this study is used to explain how every innovation in the domestication of NTPFs, is faced with challenges and resistance by the people of Manyu. The different classes of people according to Roger's (1983) categorisation have been observed in Manyu. Those that have fully adopted and 
invested in the domestication of NTFPs on farmland are making progress in the adoption of new farming techniques like grafting to reduce the production age of plants. This has increased their incomes thus, improving their living standards. Others hold that they are motivated by the proceeds from their neighbour's farms and the financial benefits they get from NTFPs and have therefore started replicating the practice on their own farms. While other informants who fear to venture into tree domestication continue to rely on plants found in the forest. This theory therefore helps to situate the level of challenges and adoption of NTFPs practices amongst the people of Manyu.

This theory also talks about the idea of product spread within a given social system. This therefore makes it suitable for this research as it is focused only on Manyu. The innovators and early adopters according to Roger's categorisation adopt innovations in the domestication of NTFPs. However, the fact that not all the people of Manyu will necessarily benefit from new innovations and the sale of NTFPs products (Rodriguez, 2009) makes the notion of 'late adopters' and 'laggards' also relevant. This is validated by the characteristics of each category mentioned in the theory of diffusion of innovations. The research question that focuses on the challenges of laggards in adopting agroforestry will be examined. The latter farmers are prone to marginalizing some actors on the one hand and on the other hand spurring up others to see the need for catching up. This category will be considered as 'leapfroggers' in this study. The study therefore permits us to identify the role of the extension works in providing training and capacity building to the farmers willing to embrace innovations.

The innovation decision process is another important aspect of this theory. This according to Rogers (1983) goes through five stages: Knowledge, persuasion, decision, implementation and confirmation. In the first stage, knowledge becomes available about an existing innovation through communication and media. In the second stage, actors are persuaded about the idea (or innovation) and this determines if they end up adopting a positive or negative attitude towards it. Depending on how persuasive the idea is, actors could adopt it or not. If adopted, it is actually implemented and the outcome or benefits will determine if actors keep or reject the innovation.

The stages by which a person adopts an innovation, and whereby diffusion is accomplished, include awareness of the need for an innovation, decision to adopt (or reject) the innovation, initial use of the innovation to test it, and continued use of the innovation.

Domestication of NTFPs is one such product that falls in the category of innovation that changes with the passage of time. NTFPs have long existed in the Manyu community. It will be interesting to understand that most of the NTFPs were found in the forest where villagers had to trek long hours to harvest. Moreover, most of these species were not planted but grow naturally in the wild. With population increase, deforestation, urbanization, the effect of climate change and more logging companies in Manyu most of these NTFP species risk extinction. As a result, there is need for alternative food sources to sustain the growing population. It is also necessary to conserve biodiversity, fight against deforestation and mitigate climate change which have become a reality to the Manyu community. NTFPs on farmland became an innovation amongst the people of Manyu. The diffusion of this idea was not easy to embrace as some of our informants hold that most NTFPs found in the forest are still very available for everybody in the community. Also, some socio-cultural factors contribute in discouraging the domestication of some of these NTFPs.

\section{DATA COLLECTION}

The study employed both secondary and primary data collection methods.

\section{SECONDARY DATA}

Secondary data were collected from reports, books and journal articles from the libraries of the Ministry of Scientific Research and Innovation (MINRESI), IITA Cameroon, ICRAF, IRAD Nkolbisson, Ministry of Agriculture and Rural Development (MINADER), and the Ministry of Forestry and Wildlife. Equally, from Ministry of Environment and Nature Protection, the various Rural Councils in Manyu, and ICRAF Mamfe. All these were done to obtain information on the situation of NTFPs vis-à-vis the existing problems. Secondary data obtained from these sources included general information on NTFPs, which was used to define the context and scope of the research. Major Socio-cultural challenges identified in the domestication of NTFPs in Manyu, the role of extensions workers and difficulties encountered. The latter information constituted the literature and was also used to compare findings of our research.

\section{PRIMARY DATA}

Primary data was collected with individual collectors of NTFPs, traders of NTFPs of priority importance (which were to be chosen by actors), and observation of extension workers and their role in enhancing the domestication of NTFPs. Four focus group discussions (FGDs) were conducted from four villages representing the subdivisions in Manyu. These villages were randomly selected and consisted of Okoyong, E'jock, Bayangbu and Bakabe. FGD respondents were our key informants selected with the use of snowballing. Respondents were between 15 to 60 years of age. This was to give the group a balance in terms of ideas with their different age brackets. To obtain information, community members were grouped while discussions were triggered from semi-structured interviews.

Eleven villages were studied out of 238 villages Manyu division. The eleven villages were randomly selected because NTFPs is highly practiced in all the villages in Manyu. Also, all the villages in Manyu had similar characteristic which made it easy to randomly select a few as representative of the study area. In most of these villages, NTFPs species were already cultivated even in the backyards of many homes. It was discovered that the eleven villages selected for the study cultivated most of the forestry species found in Manyu division.

\section{DATA ANALYSIS}

Thematic and content analysis formed the basis of our analysis. After the data collection process, common themes (topics, ideas and patterns of meaning) were identified. The socio-cultural beliefs and stereotypes which hinder farmers' domestication of NTFPs were closely examined; including issues like gender division of labour and the role of extension agents in the field. The analysis was based on issues raised and discussed with informants.

\section{RESULTS AND DISCUSSION \\ Socio-cultural beliefs preventing the domestications of NFTPs by the Manyu people}

The result of this study shows that most collectors of NTFPs species, depends on natural regeneration. It was revealed by most of our informants that it is very difficult to plant and harvest NTFPs species in one's life time. This is because it is belief that it takes a lifetime before getting to maturity. In the field, we noticed that most informants feel discourage to invest in the domestication of these tree species. 
Some informant's belief that only birds can plant forest species while others hold that animals can plant it. They belief that the seeds must go through the digestive system of animals like an elephant and porcupines which will be passed out as stool for it to geminate. This is in line with the results of Schippers (2000) and Tchoundjeu and Atangana, (2006) who observed that it may be necessary for seeds to pass through intestine of a bird, bat or other animals before they can germinate. This therefore makes some of the people in Manyu to think that domestication is not possible and it is a complete waste of time. In an interview with Mr. Besong attests that;

"The animal has to eat the seeds and pass it out as seedling before it can germinate". This tree can never grow well and bear fruits through domestication".

From field interviews, we were made to understand that the Manyu people have maintained the elephant as their main totem because of its ability to propagate indigenous seeds. Totems are therefore seen as an important element of their culture.

Over the years, njansa has been a good source of revenue for the Manyu women. Despite the tedious and timeconsuming process involved, the women interviewed in the field admitted that it fetches them a lot of money. However, due to the changes caused by the fall in the prices of cash crops like cocoa, coffee and the economic value attached this product; we observed that more men are getting involved in this activity.

Another factor that hinders the Manyu farmers from adopting the domestication of NTFPs is the competition between exotic species and these forest species. Most exotic species like cocoa, coffee, etc have more economic values, less time for maturity and have high yields. They also have the flexibility of expansion and easily colonised the area. Most often they is competition between the exotic and the NTFPs species. Our informants revealed that they prefer to plant crops that can fetch them more money than crops that they are not sure of when they can start harvesting the fruits and the amount of money, they can benefit from it.

\section{Gender division of labour}

The colonial policies and the missionaries' educational system that favoured men relegated the women to the background and this resulted to the institutionalisation of gender inequality (Boserup 1970), (Austin, 2009). This explains why certain jobs which are seen as mean and most often for subsistence are reserved for women. It was revealed that; most men think that picking of some indigenous species is work reserved for women. It is a gender role where only women are supposed to collect the fruits. This is because it is considered a mean job which cannot permit the men to get quick or fast money. Besides the process of extracting njansa nuts for example is said to be tedious and time consuming. This makes some men shy away from collecting, or processing the plant and will not like to invest in the planting or picking of Ricinodendron heudelotii "njansa". From an interview with Mami Mary a 65-year-old woman, she had this to say;

"It is not easy to pick and process njansa. In order to do so, I used to pick the seeds allow it to get rotten then I wash and boil for a couple of hours or sometimes for a whole day. During boiling, I have to laugh in order that the nuts should get cracked without which I will not be able to remove the nuts from the shells. The nuts are actually the njansa that is used as food or sold in the markets".
Mr. Ayuk on his part had this to say:

I am a man with two wives and a title holder and cannot carry out duties like picking njansa and other fruits. It is a mean job reserved for women and children. No reasonable man can do such a mean job".

The two citations above confirm the fact that picking of NTFPs is a women's world and not that of men. It implies that the men in Manyu do not yet recognise the economic value of this sector of production and therefore do not yet see domestication as a priority. Women as well still uses the fruits as a means of subsistence while the left over is meant for the markets.

\section{Role of the extension agents}

Many of our informants especially those found in the rural areas admitted to have had no contact with agricultural extension officers working in Manyu division. The few who said that they had worked with the extension agents were found in the Mamfe town. These few farmers who are involved in the cultivation of NTFPs said they had irregular visits of extension worker to their farms. The extension workers according to the farmers did more of theory than practical with them as they educated them on domestication, and little or no knowledge on how to plant and cater for the trees.

Also, most of the extension agents interviewed complained that some of the farmers are very slow and unwilling to learn innovative ideas. This was very common amongst those that were not educated because their level of comprehension of nursery techniques and modern conservation strategies is very low. It was revealed that, NTFPs farmers with more experiences in mainstream farming easily adopt innovations. This finding is in line with studies by ICRAF, (2001) which shows that farmers with more experience in farming are likely to adopt new technologies since they can better understand the benefits of innovation based on their various experiences. Again extension agents said that they preferred to work with younger farmers. This is because, according to the extension agents, younger farmers are more likely to adopt new technologies than the older farmers since they have acquired more education and have been exposed to new ideas gotten from other towns. This finding was also confirmed by ICRAF, (2001).

Some NTFPs farmers complained that extension agents most often do not listen to them and therefore impose their ideas which they sometime reject. Like the case of informants who belief that their parents never planted these indigenous plants and can never be planted. They believe that these species will always be available in the wild for everybody to consume. Therefore, there is no need for domestication. Language barrier was also seen as an obstacle to innovation especially amongst the uneducated thus making communication very difficult.

Again, some farmers complained that seminars for education on domestication are limited and often take place at the divisional and subdivsional levels which are not accessible to most of the farmers who live in enclave zones with poor transportation networks. Farmers, said that they are little or no demonstration farms in most of the communities to teach farmers on nursery techniques and modern conservation strategies.

\section{Farmers' attitudes towards planting NTFPs}

In most rural communities visited, we noticed the unwillingness of farmers to domesticate NTDPs. However, we found some few farmers who attested to the fact that they were willing to domesticate NTFPs if given the opportunity. 
TABLE 1: Reasons for farmers' (un) willingness to plant indigenous trees species

\begin{tabular}{|l|l|}
\hline \multicolumn{1}{|c|}{ REASONS FOR WILLINGNESS TO PLANT } & \multicolumn{1}{c|}{ REASONS FOR UNWILLINGNESS TO PLANT } \\
\hline For future generations & Resources are abundant in the forest \\
\hline Increase income & Ignorance on planting techniques \\
\hline increase production & Trees grow naturally or are planted by God \\
\hline facilitate access to product & In their natural form. (better quality) \\
\hline ensure ownership & Have other sources of Income \\
\hline improve quality through selection & Job reserved for women \\
\hline Increase diversification on farmland. & \\
\hline
\end{tabular}

The reasons outlined by villagers on willingness to plant NTFPs indicate that there is growing awareness on the importance of these species in these communities, both for the present and future generations. The fact that some people are unwilling to plant these species was because they have been used to gathering these products for generations and it is freely avaliable to everybody. Most villagers that had NTFPs on their farms were those who owned cocoa plantations with large surface areas and plant these species not only for fruits, income, but also for shade provision and soil fertility improvement. This idea was supported by Awono et al., 2002; Fondoun et al., (1999) I. gabonensis and R. heudelotii are among the species found in most cocoa agroforests in Cameroon.

It was also observed that some farmers indicated that the major causes of their unwillingness to domesticate NTFPs were post-harvest losses caused by poor drying and prolonged storage. I. gabonensis and R. heudelotii fruits were usually collected during the rainy season, making the drying process very difficult. This made it difficult for farmers to preserve fruits and sell during periods of scarcity in order to make more profits, but I. gabonensis almonds (most highly traded in the study area) cannot last for long (about 6 months) leading to some loss through rot, especially when stored for long periods.

\section{CONCLUSION}

The idea of domestication of NTFPs is not new the Manyu people but its adoption has been very slow. This is because the people have many cultural stereotypes that they are still very attached to. Despites efforts made by the extension workers and Non-Governmental Organisations working in the field, the people of Manyu division still attach to socio cultural beliefs that prevent them from adopting innovations. This implies that it is not easy for a society to change its food ways and food practices and to accept innovations which they think cannot bring them immediate benefits. Some respondent's belief that, if they plant some tree species, they may not be able to harvest in their life time. The study therefore recommends that, a holistic approach is needed to develop the right conditions to promote NTFPs domestication in Manyu division. This approach will involve sensitization, creation of demonstration farms and more training sessions. The study also recommends more elaborate government policies that will help in the integration of NTFPs products into food supply chain and healthcare system. The importance of NTFPs in increasing food access, increase income and its medicinal values are growing evidence of the importance of NTFPs in many rural communities. Hence there is need at institutional level to encourage rural communities who are already involved in this form of agriculture.

\section{REFERENCES}

[1] Arnold J.E.M., (1997). Framing the issues. Pp. 3-20 in Arnold J.E.M. and Dewees, P.A. (eds). Farms, trees and farmers: Responses to agricultural intensification. Earthscan, London.

[2] Awono, A., Ndoye, O., Schreckenberg, K., Tabuna, H., Isseri, F. and Temple, L. (2002). Production and marketing of Safou (Dacryodes edulis) in Cameroon and internationally: Market development issues. Forest, Trees and Livelihoods 12, 125 - 147.

[3] Ajake, Anim 0. (2012). The Role of Forest Trees in Indigenous Farming Systems as a Catalyst for Forest Resources Management in the Rural Villages of Cross River State, Nigeria. Global Journal of HUMAN SOCIAL SCIENCE Geography \& Environmental GeoSciences Volume 12 Issue 13 Version 1.0 Year 2012. Online ISSN: 2249-460x \& Print ISSN: 0975-587X

[4] Ayuk, E. T., Duguma, B., Franzel, S., Kengue, J., Mollet, M., Tiki Manga, T. and Zenkeng, P. (1999). Uses, management and economic potential of Irvingia gabonensis in the humid lowlands of Cameroon. Forest Ecology and Management, 113 (1): 1-9.

[5] Boserup, E. (1965). The conditions of agricultural growth under population pressure Aldine Publishing Company Chicago, P. 124.

[6] Belcher, B. M. (2005) Forest product markets, forests and poverty reduction. International Forestry Review 7 (2): 82-89.

[7] De Beer, J. (2011) On forest foods, a festival and community empowerment. CFA Newsl. a. 54:1-5.

[8] Ewane, M., Ingram, V. \& Awono, A. (2009). Market chain baseline for bush mango (Irvingia spp.) in the South West and Eastern Regions of Cameroon. Project Report, CIFOR, Cameroon.

[9] Fondoun, J. M., Tiki, M. T., \& Kengue J. (1999). Ricinodendron heudelotii (njangsang). Ethnobotany and importance for forest dwellers in Southern Cameroon.Plant-Genetic-Resources Newsletter, 118: 1-6.

[10] Gillet, P., Vermeulen, C., Doucet, J., Codina, E., Lehnebach, C.,1 and Feintrenie, L. (2016)

[11] What are the impacts of deforestation on the harvest of non-timber forest products in Central Africa? Forests, 7, 106, 1-15.

[12] Gockowski, J., Tonye, J. \& Baker, D. (1997). Characterisation and diagnosis of agricultural systems in the Alternatives to Slash and Burn forest margins benchmark of southern Cameroon. 
[13] Ingwe, R., Ikeji C.C.C. \& Walter, M. (2010). Forestry, Poverty Alleviation and Human Livelihoods support in Cross River State, Nigeria: An analysis of subnational agro-forestry development policy in a poverty-stricken bioregion. Journal of Sustainable Development in Africa (Volume 12, No.2, 2010) pp412-442.

[14] International Centre for Research in Agroforestry, Trees and food security in Africa; what's the link? http://blog.worldagroforestry.org. Accessed on $05^{\text {th }}$ August 2017.

[15] Leakey, R. R. B., Tchoundjeu. Z., Schreckenberg, K., Shackleton, S. E. \& Shackleton, C. M (2005). Agroforestry Tree Products (AFTPs): Targeting Poverty Reduction and Enhanced Livelihoods. Pages 1-23 Published online: 06 Jun 2011 http://dx.doi.org/10.1080/14735903.2005.9684741

[16] Rogers, E.M. (1983). Diffusion of Innovations. MacMillan, London, 447p.

[17] Rodriguez C.L. (2009). Social Media in Tourism. MA theses in European Tourism Management Bournemouth University. $88 \mathrm{p}$.

[18] Moupela, C., Vermeulen, C., Daïnou, K., Doucet, J. L. (2011) Le noisetier d'Afrique (Coula edulis Baill.). Un produit forestier non ligneux méconnu. BASE Biotecnol. Agron. Soc Environ. 15, 451-461.

[19] Ndoye O., Ruiz P. M., \& Ayebe A. (1997) The Markets of non-timber forests products in the humid forest zone of Cameroon. Rural Development Forestry Network Paper22c, London Overseas Development Institute.

[20] Shahin I. (2006). Detailed Review of Roger's Diffusion of Innovations Theory and Educational Technology-Related Studies Based on Rogers' Theory, The Turkish Online Journal of Educational Technology, vol.5. 14-23pp.
[22] Schippers, R. R. (2000). African indigenous vegetables: an overview of the cultivated species. U.K.: Natural Resources Institute/ACP/EU Technical Centre for Agriculture and Rural Cooperation.

[23] Schreckenberg K., Awono A., Degrande A., Mbosso C., Ndoye 0., And Tchoundjeu Z. (2006). Domesticating indigenous fruit trees as a contribution to poverty reduction. Overseas Development Institute, 111 Westminster Bridge Road, London SE1 7JD Centre for International Forestry Research, BP 2008, Yaoundé, Cameroon, World Agroforestry Centre, BP 16317,

Vol. 16, pp. 35-51 Yaoundé, Cameroon https://www.tandfonline.com/doi/abs/10.1080/1472 8028.2006.9752544

[24] Ruiz-Pérez, M., Belcher, B., Achdiawan, R., Alexiades, M., Aubertin, C., Caballero, J., Campbell, B., Clement, C., Cunningham, T., Fantini, A., de Foresta, H., Fernández, C. G., Gautam, K. H., Hersch, P. M., de Jong, W., Kusters, K., Kutty, M. G., López, C., Fu, M., Martinez Alfaro, M. A., Nair, T. K. R., Ndoye, O., Ocampo, R., Rai, N., Ricker, M., Schreckenberg, K., Shackleton, S., Shanley, P., Sunderland, T., and Youn, Y.-C. (2004)

[25] Markets drive the specialization strategies of forest peoples. Ecol Soc 9 (2): 4.

[26] Rogers, E.M. (1983). Diffusion of Innovations. MacMillan, London, 447p.

[27] O'Sullivan (2008). Defining Innovation. SAGE publications, innovation. p.4

[28] World Bank (2008) World Development Report 2008. Agriculture for Development. World Bank, Washington, USA.1/9/2017

[29] Tchoundjeu, Z., \& Atangana, A. R. (2006) Ricinodendron heudelotii (Baill.) Southampton Centre for Underutilized Crops. University of Southampton: Southampton, UK, 74. 